\title{
DYNAMIC MODELING OF A SINGLE-LINK FLEXIBLE MANIPULATOR ROBOT WITH TRANSLATIONAL AND ROTATIONAL MOTIONS
}

\author{
DERMAWAN DERMAWAN ${ }^{1,2^{*}}$, HAMMADA ABBAS ${ }^{1}$, RAFIUDDIN SYAM ${ }^{1}$, \\ ZULKIFLI DJAFAR $^{1}$ AND ABDUl KADIR MUHAMMAD ${ }^{2}$ \\ ${ }^{1}$ Department of Mechanical Engineering, Hasanuddin University, \\ Gowa-Makassar, Indonesia. \\ ${ }^{2}$ Department of Mechanical Engineering, State Polytechnic of Ujung Pandang, \\ Makassar, Indonesia \\ *Corresponding author: dermawan@poliupg.ac.id
}

(Received: $26^{\text {th }}$ August 2019; Accepted: $27^{\text {th }}$ November 2019; Published on-line: 20 th January 2020)

\begin{abstract}
The flexible manipulator is widely used in space robots, robot arm, and manufacturing industries that produce micro-scale products. This study aims to formulate the equation of motion of a flexible single-link manipulator system that moves translationally and rotationally and to develop computational codes with the finite-element method in performing dynamic simulation on the vibration of the flexible manipulator system. The system of the single-link flexible manipulator (SLFM) consists of an aluminium beam as a flexible link, a clamp part to hold the link, a DC motor to rotate the drive shaft, a trajectory to transfer the link in translational motion, and a servo motor to rotate the link. Computational codes in time history response (THR) and Fast Fourier Transform (FFT) processing were developed to identify the dynamic behaviour of the link. The finite-element method and Newmark-beta are used in simulating the SLFM. Simulation using the finite-element method has displayed dynamic behaviour through a graph of FFT on free vibration and THR graph on forced vibration by the excitation force due to the translational and rotational motions of the system. FFT has also generated natural frequency values as $(f) 8.3[\mathrm{~Hz}]$. For translational and rotational motions, lateral deformation gets the maximum deviation at the value 0.0077 [m] and the minimum deviation $-0.0085[\mathrm{~m}]$ at $\mathrm{t}=0[\mathrm{~s}]$. While at time $\mathrm{t}=0.5[\mathrm{~s}]$ due to the existence of the excitation force at the time, the maximum deviation at the value $-0.009[\mathrm{~m}]$, and the minimum deviation $-0.0085[\mathrm{~m}]$.
\end{abstract}

ABSTRAK: Pemanipulasi fleksibel banyak digunakan dalam robot angkasa, lengan robot, dan industri pembuatan yang menghasilkan produk skala-mikro. Kajian ini bertujuan mengformulasi persamaan pergerakan sistem manipulasi pautan-tunggal fleksibel yang bergerak secara realisasi dan putaran dan bagi membina kod pengkomputeran dengan kaedah unsur-terhingga dalam membuat simulasi dinamik pada getaran sistem manipulasi fleksibel. Sistem manipulasi pautan-tunggal fleksibel (SLFM) terdiri daripada alur aluminum sebagai pautan fleksibel, bahagian pengapit bagi memegang pautan, motor DC bagi memutar pandu aci, trajektori bagi memindahkan pautan dalam gerakan realisasi, dan motor servo bagi memutar pautan. Kod pengkomputeran dalam Sambutan Respons Masa (THR) dan proses Penjelmaan Fourier Pantas (FFT) telah dibina bagi mengenal pasti kelakuan dinamik pada pautan. Kaedah unsur-terhingga dan beta-Newmark telah digunakan dalam simulasi SLFM. Simulasi menggunakan kaedah unsur-terhingga menunjukkan kelakuan dinamik melalui graf FFT pada bebas getaran dan graf THR pada getaran paksaan melalui ujaan paksa bagi membentuk realisasi dan gerakan putaran pada sistem. FFT juga menghasilkan nilai frekuensi semula jadi sebagai $(f) 8.3$ [Hz]. Bagi 
realisasi dan gerakan putaran, sisihan perubahan bentuk maksimum ialah pada nilai 0.0077 $[\mathrm{m}]$ dan sisihan minimum $-0.0085[\mathrm{~m}]$ pada $\mathrm{t}=0[\mathrm{~s}]$. Sementara pada masa $\mathrm{t}=0.5[\mathrm{~s}]$ bergantung pada ujaan paksa yang hadir pada masa tersebut, sisihan maksimum ialah pada nilai -0.009 [m], dan sisihan minimum ialah $-0.0085[\mathrm{~m}]$.

KEYWORDS: dynamic modelling; single-link flexible manipulator; finite-element method; time history response; translational and rotational motions

\section{INTRODUCTION}

In industrial applications and robotic systems, single-link flexible manipulators (SLFM) are expected to work optimally during operation. Researchers who study flexible manipulators for space can be found in many reputable journals, such as [1-6]. For the application of space robots, a manipulator robot is designed to lift relatively small objects such as rock samples and remove existing obstacles so that the manipulator must be able to carry out operations with better positioning accuracy. Lower weight aims to save load capacity and reduce the cost of rocket launches and reduce energy consumption. SLFM has limitations with frequent vibrations that cause system performance to be interrupted. Therefore, further research is needed to describe the dynamic conditions of the SLFM. Several studies have investigated the performance and control system of the SLFM. Qiu [7] reviewed two main parts of the flexible Cartesian manipulator (FCM), explicitly the control algorithm and validated it with the experiment. The FCM used Fiberglass colophony material. The FCM experiment only displayed translational motion along the $Y$-axis $(O-Y$ $O)$. Conversely, Shin and Rhim [8] conducted modelling with the Newtonian approach to horizontal translational motion $(O-X-O)$ on the flexible link. The modelling result showed the effect of lateral vibration and dynamic stiffness at varying frequencies of the beam. Yang et al. [9] designed an observation using partial differential equations (PDE) using kinetic energy and potential energy methods to predict vibration, unlimited dimensional condition by only requiring practical measurement values from a boundary position. From the simulation result, the vibration can be removed using PD control.

The research done by Ata et al. [10] is somewhat different. They used an Euler Bernoulli approach on SLFM, where a flexible beam is considered rigid and marked by a straight line that extends from point $\mathrm{O}$ to the end of the beam, called a virtual link (VL), which is perpendicular to the tangent vector line. The beam on VL moves rotationally. Still, on the SLFM, Muhammad et al. [12-15] carried out comprehensive simulations and experiments with the FEM, PD, and AF control approaches to vibration on the SLFM. They [16-18] also added a piezoelectric actuator on aluminium-based links, which generate stress on two Degrees of Freedom (DOF). Meanwhile, Mahto [18], still in the rotation movement of the SLFM, has investigated it using the finite-element method (FEM) approach with five DOF assuming the link manipulator as a Euler-Bernoulli beam.

A myriad of investigations on the flexible manipulator using FEM in analysing vibration has been reported in the literature such as essential modelling replacement in control algorithm [19], a multi-link flexible robotic manipulator with a smart piezoelectric transducer [20], vibration control of a single-link flexible composite manipulator [21]. Finite-element modelling with the piezo-integrated structure using Hamiltonian principles [22], and free vibration analysis on a thin-plate [23]. Based on several studies, in general, they researched the SLFM system with just one motion: translation or rotation. If the SLFM is applied in industry, it generally uses two movements simultaneously, that is to say, translational and rotational motions. The problem is the lack of research that combines 
translational and rotational motions of the SLFM system, which results in inaccurate positioning. Therefore, this research will to do a more in-depth study.

Several similarities were also identified with existing research, such as the use of Lagrange's equation, kinetic energy, and potential energy to derive the equation of motion [24]. The difference is, Bien's work focuses on the combination of translational and rotational movements of a two-link manipulator, where the first link moves horizontally, and the second link moves rotationally. Dermawan et al. [25] have found the equation of translational movement in SLFM using the finite-element method. Research from Muhammad et al. [17] as the primary reference in this research, that has formulated the equation of rotational motion at SLFM, becomes interesting to develop by combining translational and rotational movements.

The purpose of this study is to formulate the equation of motion and compose computational codes by FEM on the SLFM system that moves translationally and rotationally. This research used FEM in carrying out dynamic simulations of the SLFM system. The results of the simulation showed the vibration dynamics of the order by displaying a Time History Response (THR) and Fast Fourier Transform (FFT) processing of the system.

\section{DYNAMIC MODELLING}

Based on the kinematic model of the SLFM that moves translationally, as shown in Fig. 1, the position vector of point $P$ moves translationally at the $O-Y$ coordinate. The link moves translationally in the horizontal direction at the coordinates $O-Y p$ as far as $Y$, and $v_{p}$ is the lateral deformation to point $P$. The base of the link experiences a positive displacement on the $Y$-axis as now as $O-y$, the positive $X$-axis at position $X_{p}=x_{p}$, and the end of the link is a position vector $P$. The position vector $\mathrm{r}(x, t)$ at point $P$ on the link at $t=t$, is represented in the $O-X-Y$ coordinates.

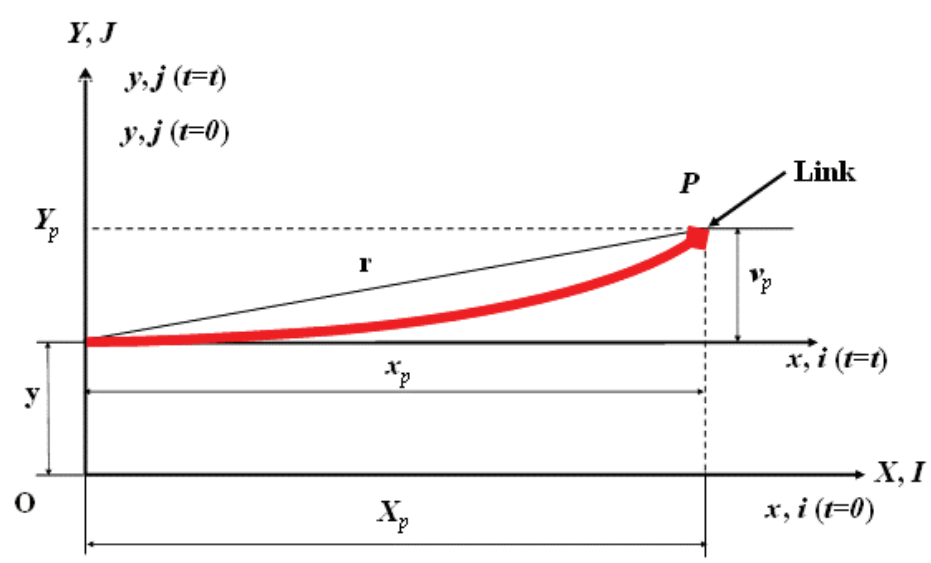

Fig. 1: The position vector of point $P$ on the link that moves translationally.

The position vector of point $P$ in the $O-X-Y$ coordinates is

$$
r(x, t)=X_{p}(x, t) \boldsymbol{I}+Y_{p}(x, t) \boldsymbol{J},
$$

where;

$$
\begin{aligned}
& X_{p}(x, t)=x_{p}, \\
& Y_{p}(x, t)=y+v_{p} .
\end{aligned}
$$


The velocity vector of point $P$ in the coordinates $O-x-y$ is given with

$$
\dot{\boldsymbol{r}}(x, t)=\dot{X}_{p}(x, t) \boldsymbol{I}+\dot{Y}_{p}(x, t) \boldsymbol{J} .
$$

\subsection{Equation of Motion using the Finite-Element Method}

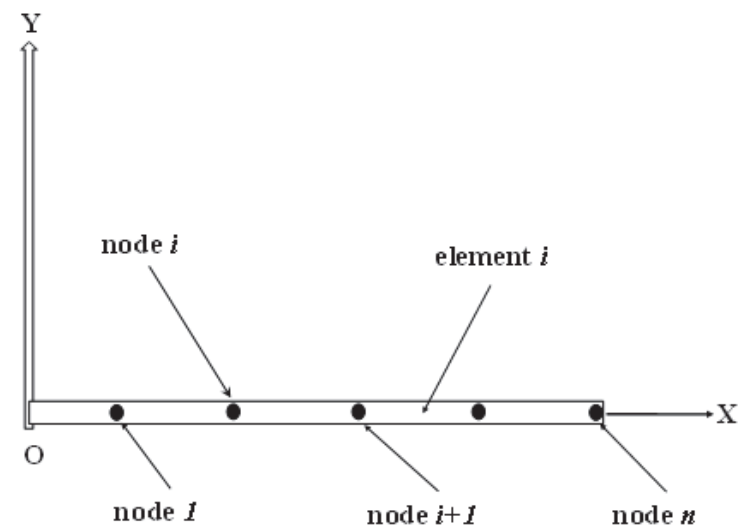

Fig. 2: The translational coordinate of the link.

This paper uses the finite-element method approach, where each partition on the link is presently divided into several elements. The aim is to find out the mass matrix $(M)$ and the stiffness matrix $(K)$, that will be used to simulate the dynamics of the system. The system dynamics model is a cantilever structure that is partitioned into six elements and six-node points. Fig. 2 show the translational coordinate X-Y divided by one-dimension and twonode elements with four boundary conditions together at node $i$ and $i+1$.

An element of the link is shown in fig. 3. The finite-element has two DOF, called the lateral deformation of the $i$-th element $\left(v_{i}\right)$ and slope $\left(\varphi_{i}\right)$. The physical properties of the system consist of the length of the link $(\mathrm{Li})$, the cross-sectional area of the link ( $\mathrm{Si}$ ), and the moment of inertia ( $I i)$. Each element has mechanical properties, namely Young's modulus and mass density, which are denoted by $E i$ and $\rho$ i.

The nodal displacement vector is expressed by

$$
\delta_{i}=\left[v_{i}, \varphi_{i}, v_{i+1}, \varphi_{i+1}\right],
$$

with

$$
v_{i}=a_{1}+a_{2} x_{i}+a_{3} x_{i}{ }^{2}+a_{4} x_{i}{ }^{3} .
$$

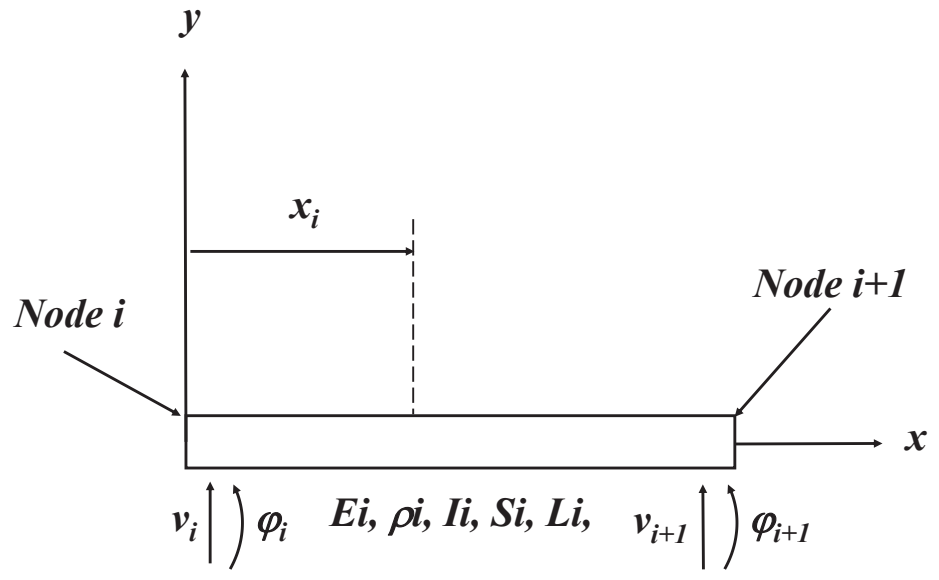

Fig. 3: Nodal displacement of the link. 
In the discretization process, the equation of translational motion can be achieved as follows;

Acceleration of $P$ can be written by

$$
\dot{\boldsymbol{r}}^{T} \cdot \dot{\boldsymbol{r}}=\dot{x}_{p}^{2}+\dot{y}^{2}+\dot{v}_{p}^{2}+2 \dot{y} \dot{v}_{p} .
$$

The general articulation of kinetic energy $(T)$, with $(V)$ being the velocity, can be expressed by

$$
T=\frac{1}{2} \int_{v} \rho \cdot V^{2} d v
$$

Kinetic energy $\left(T_{i}\right)$ of the system is given by

$$
T_{i}=\frac{1}{2} \int_{v_{i}} \rho_{i} \cdot \dot{\boldsymbol{r}}^{T} \cdot \dot{\boldsymbol{r}} \cdot d v_{i}
$$

So that kinetic energy of translation motion $\left(T_{i} t\right)$ for the system can be written as

$$
T_{i} t=\frac{1}{2} m_{i} \dot{x}_{p}{ }^{2}+\frac{1}{2} m_{i} \dot{y}^{2}+\frac{1}{2} \dot{\delta}_{i}^{T} M_{i} \dot{\delta}_{i}+\dot{y} f_{t_{i}}{ }^{T} \dot{\delta}_{i},
$$

where

$$
\dot{y} f_{t_{i}}{ }^{T} \dot{\delta}_{i}=\frac{m_{i}}{12}\left[\begin{array}{llll}
6 & l_{i} & 6 & -l_{i}
\end{array}\right] .
$$

The potential energy $\left(U_{i}\right)$ of the system is

$$
U_{i}=\frac{1}{2} \delta_{i}^{T} K_{i} \delta_{i}
$$

The dissipation function $\left(R_{i}\right)$ of the system is

$$
R_{i}=\frac{1}{2} C_{i} \dot{\delta}_{i}^{2} .
$$

The mathematical model of a dynamic system using the Lagrange's equation is written with

$$
\frac{d}{d t}\left(\frac{\partial T}{\partial \dot{q}_{k}}\right)-\frac{\partial T}{\partial \dot{q}_{k}}+\frac{\partial U}{\partial \dot{q}_{k}}+\frac{\partial R}{\partial \dot{q}_{k}}=Q_{k} .
$$

If we substitute variables from Eq. (14) as follows:

$$
\frac{d}{d t}\left(M_{i} \dot{\delta}_{i}-\dot{y}(t) f_{t i}{ }^{T}\right)+K_{i} \delta_{i}+\frac{\partial R}{\partial \dot{q}_{k}}+C_{i} \dot{\delta}_{i}=Q_{k} .
$$

Furthermore,

$$
M_{i} \ddot{\delta}_{i}-\ddot{y}(t) f_{t i}^{T}+C_{i} \dot{\delta}_{i}+K_{i} \delta_{i}=0 .
$$

So that the equation of motion for the $i$-th element gives

$$
M_{i} \ddot{\delta}_{i}+C_{i} \dot{\delta}_{i}+K_{i} \delta_{i}=\ddot{y}(t) f_{t i}{ }^{T} .
$$

Matrix $M_{i}, C_{i}, K_{i}$, and $\ddot{y}(t) f_{t i}{ }^{T}$ are the mass matrix, damping matrix, stiffness matrices, and excitation forces of the DC motor, respectively. Matrix $M_{i}, C_{i}, K_{i}$ is an element of the equation contained in Eq. (17) is a representation of;

$$
M_{i}=\frac{\rho_{i} S_{i} L_{i}}{420}\left[\begin{array}{cccc}
156 & 22 L_{i} & 54 & -13 L_{i} \\
22 L_{i} & 4 L_{i}{ }^{2} & 13 L_{i} & -3 L_{i}{ }^{2} \\
54 & 13 L_{i} & 156 & -22 L_{i} \\
-13 L_{i} & -3 L_{i}{ }^{2} & -22 L_{i} & 4 L_{i}{ }^{2}
\end{array}\right]
$$




$$
\begin{aligned}
K_{i} & =\frac{E_{i} I_{i}}{L_{i}{ }^{3}}\left[\begin{array}{cccc}
12 & 6 L_{i} & -12 & 6 L_{i} \\
6 L_{i} & 4 L_{i}{ }^{2} & -6 L_{i} & 2 L_{i}{ }^{2} \\
-12 & -6 L_{i} & 12 & -6 L \\
6 L_{i} & 2 L_{i}{ }^{2} & -16 L_{i} 4 L_{i}{ }^{2}
\end{array}\right], \\
C_{i} & =\alpha \cdot K_{i} .
\end{aligned}
$$

While the translational motion of the force vector is

$$
f_{t i}^{T}=-\frac{\rho_{i} S_{i} L_{i}}{12}\left\{6, l_{i}, 6,-l_{i}\right\} .
$$

The length of the $i$-th element is the length from the first element to $i$, with the symbols $l_{i}$ and $l_{1+i}$.

Equation of translational motion of the SLFM with $i$-th element based on boundary conditions is written with;

$$
M_{n} \ddot{\delta}_{n}+C_{n} \dot{\delta}_{n}+K_{n} \delta_{n}=\ddot{y}(t) f_{t_{n}} .
$$

The kinetic energy of rotational motion $\left(T_{i} r\right)$ of the system has been formulated in [11] as follows

$$
T_{i} r=\frac{7}{6} m_{i} l_{i}^{2} \dot{\theta}^{2}+\frac{1}{2} \dot{\delta}_{i}^{T} M_{i} \dot{\delta}_{i}+\frac{1}{2} \delta_{i}{ }^{T} \dot{\theta}^{2} M_{i} \delta_{i}+\dot{\theta} f_{r_{i}}{ }^{T} \dot{\delta}_{i} .
$$

And then the rotational force vector is written with

$$
\ddot{\theta}(t) f_{n}=\frac{\rho_{i} s_{i} L_{i}}{60}\left\{30 l_{1-i}+9 l_{i}, 5 l_{1-i} l_{i}+2 l_{i}^{2}, 21 l_{i},-5 l_{1-i} l_{i}+3 l_{i}^{2}\right\} .
$$

Equation of motion of the $i$-element is written by [12],

$$
M_{n} \ddot{\delta}_{n}+C_{n} \dot{\delta}_{n}+\left(K_{n}-\dot{\theta}^{2}(t) M_{n}\right) \delta_{n}=\ddot{\theta}(t) f_{n} .
$$

where $\ddot{\theta}(t) f_{r i}{ }^{T}$ the respective excitation forces.

To find the kinetic energy of the system, kinetic energy caused by translational and rotational motions is obtained by combining kinetic energy from translational motion and rotational motion so that the kinetic energy of translational and rotational motions $\left(T_{i} t r\right)$ of the system will be obtained;

$$
T_{i} t r=T_{i} t+T_{i} r .
$$

From the discretization result of the kinetic energy of translational and rotational motions, then by substituting Eq. (10) and (23) into Eq. (26) becomes

$$
T_{i} t r=\frac{5}{3} m_{i}\left(\dot{x}_{p}{ }^{2}+\dot{y}^{2}+l_{i}{ }^{2} \dot{\theta}^{2}\right)+\dot{\delta}_{i}{ }^{T} M_{i} \dot{\delta}_{i}-\frac{1}{2} \delta_{i}{ }^{T} \dot{\theta}^{2} M_{i} \delta_{i}-\left(\dot{y} f_{t_{i}}{ }^{T}+\dot{\theta}{f_{r}}{ }^{T}\right) \dot{\delta}_{i} .
$$

Applying Lagrange's equation, then substitution Eq. (27) to Eq. (14) gives

$$
\begin{aligned}
& \frac{d}{d t}\left(2 M_{i} \dot{\delta}_{i}-\left(\dot{y} f_{t_{i}}{ }^{T}+\dot{\theta} f_{r_{i}}{ }^{T}\right)-\dot{\theta}^{2} M_{i} \delta_{i}+K_{i} \delta_{i}+C_{i} \dot{\delta}_{i}=0,\right. \\
& 2 M_{i} \ddot{\delta}_{i}-\left(\ddot{y} f_{t_{i}}{ }^{T}+\ddot{\theta} f_{r_{i}}{ }^{T}\right)+\left(K_{i}-\dot{\theta}^{2} M_{i}\right) \delta_{i}+C_{i} \dot{\delta}_{i}=0 .
\end{aligned}
$$

From the results of discretization using Lagrange's equation, the equation of translational and rotational motions for the $i$-element becomes

$$
2 M_{i} \ddot{\delta}_{i}+C_{i} \dot{\delta}_{i}+\left(K_{i}-\dot{\theta}^{2} M_{i}\right) \delta_{i}=\left(\ddot{y} f_{t_{i}}{ }^{T}+\ddot{\theta} f_{r_{i}}{ }^{T}\right) .
$$

Finally, the equation of translational and rotational motions of the system can be written 
$2 M_{n} \ddot{\delta}_{n}+C_{n} \dot{\delta}_{n}+\left(K_{n}-\dot{\theta}^{2} M_{n}\right) \delta_{n}=\left(\ddot{y} f_{t_{n}}{ }^{T}+\ddot{\theta} f_{r_{n}}{ }^{T}\right)$.

\section{COMPUTATIONAL MODEL}

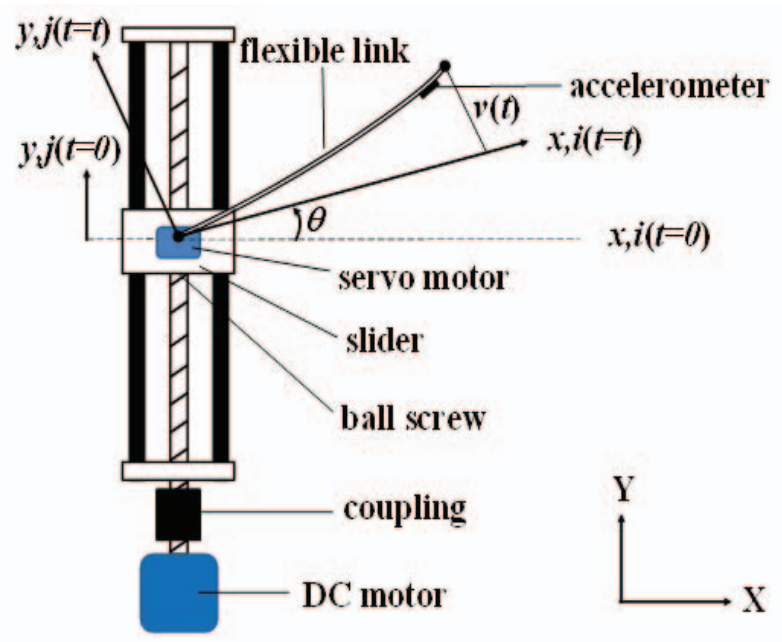

Fig. 4: Physical model of the SLFM.

Figure 4 shows the physical model of the SLFM robot. The SLFM consists of an aluminium beam, a track of the link, a clamp-part, a servo motor to rotate of the link, and a DC motor to make translational motion using a ball screw mechanism. The link, including the clamp-part, is more rigid than the link alone. Furthermore, at the end of the link, an accelerometer is installed to detect vibration that occurs in the system.

Figure 5 shows an illustration set-up of the SLFM system. On the microcontroller, there is a switch to regulate translational and rotational motions on the SLFM system. The switch consists of On-Off buttons, translational motion, translational and rotational motions, and direction of movement. There is a USB connector for connecting the vibration sensor accelerometer to a computer program.

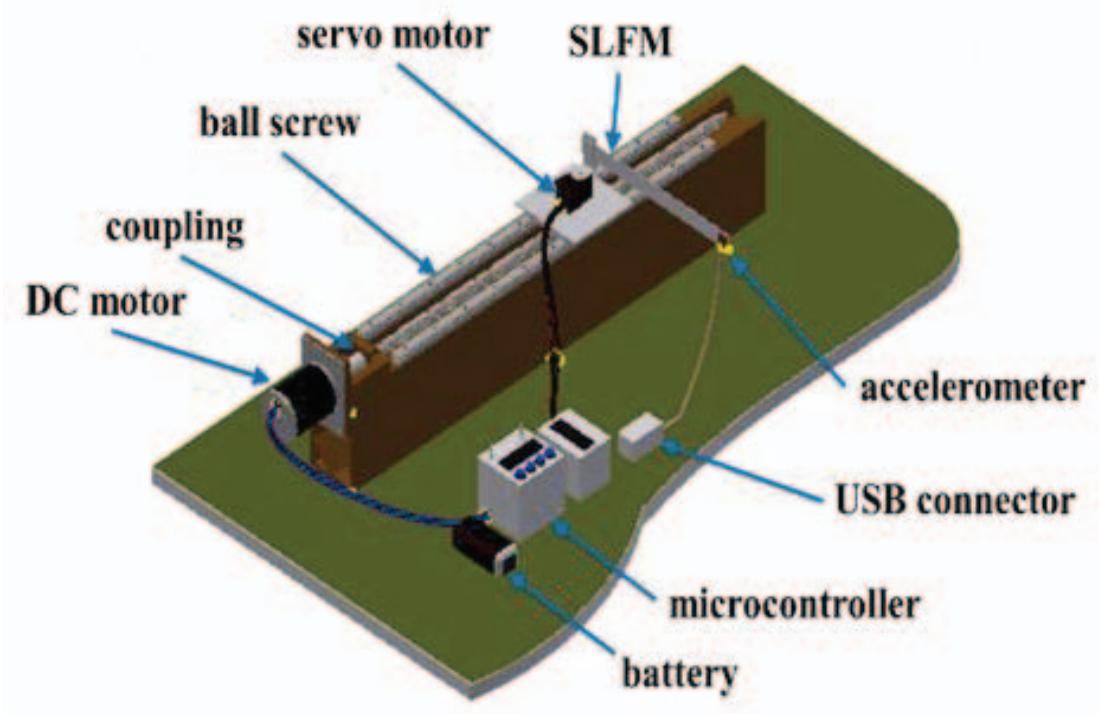

Fig. 5: Illustration set-up of the SLFM. 
Table 1: Physical parameters of the SLFM.

\begin{tabular}{lcc}
\hline \multicolumn{1}{c}{ Property } & Symbol & Value \\
\hline Total length $[\mathrm{m}]$ & $L$ & $3.30 \times 10^{-1}$ \\
Length of the link $[\mathrm{m}]$ & $l_{i}$ & $3.00 \times 10^{-1}$ \\
Breadth of cross section $[\mathrm{m}]$ & $b_{i}$ & $2.50 \times 10^{-2}$ \\
Height of cross section $[\mathrm{m}]$ & $h_{i}$ & $1.00 \times 10^{-3}$ \\
Cross-section area of the link $\left[\mathrm{m}^{2}\right]$ & $S_{i}$ & $1.95 \times 10^{-5}$ \\
Cross-section area moment of inertia Around $i-$ & $I_{i}$ & $2.75 \times 10^{-12}$ \\
axis of the link [m $\left.{ }^{4}\right]$ & & \\
Young's Modulus of the link $\left[\mathrm{N} / \mathrm{m}^{2}\right]$ & $E_{i}$ & $7.00 \times 10^{10}$ \\
The mass density of the link $\left[\mathrm{kg} / \mathrm{m}^{3}\right]$ & $\rho_{i}$ & $2.70 \times 10^{3}$ \\
The viscous damping ratio of the link & $\alpha$ & $0.10 \times 10^{-3}$ \\
\hline
\end{tabular}

\section{RESULTS}

\subsection{Time History Response on Free Vibration}

Figure 6 shows the time history response of lateral deformation $V p$ on free vibration. The lateral deformation was simulated using impulse force as an external force. In this section, the DC motor and servo motor have not moved. The computational code has been generated at a nodal point six on the THR of lateral deformation. The minimum deviation is at the value $-0.009[\mathrm{~m}]$, and the maximum difference is $0.0078[\mathrm{~m}]$.

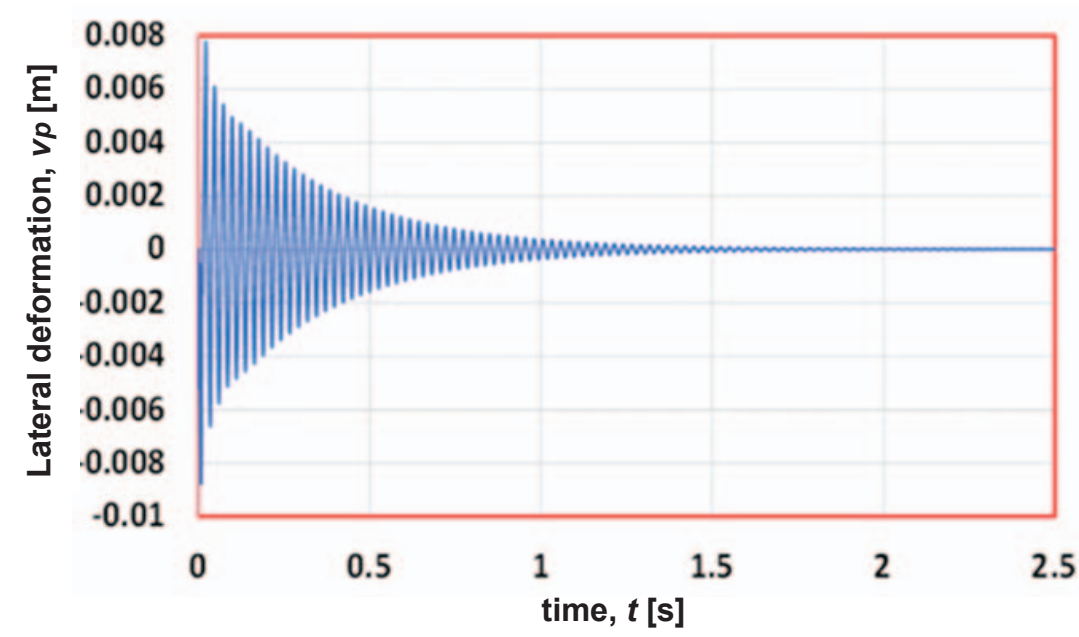

Fig. 6: THR on the free vibration of the SLFM.

\subsection{Fast Fourier Transform Processing}

The results obtained from simulation with free vibration on the system, are then transferred by the FFT process to get the value of the natural frequency of the magnitude. Figure 7 shows the result of a simulation of the natural frequency of the SLFM system. The FFT graph shows that the natural frequency $(f)$ is $8.3[\mathrm{~Hz}]$. When compared using the calculation method, a natural frequency of the order obtained is $9.1[\mathrm{~Hz}]$, so it can be concluded that the simulation results can be validated correctly. 


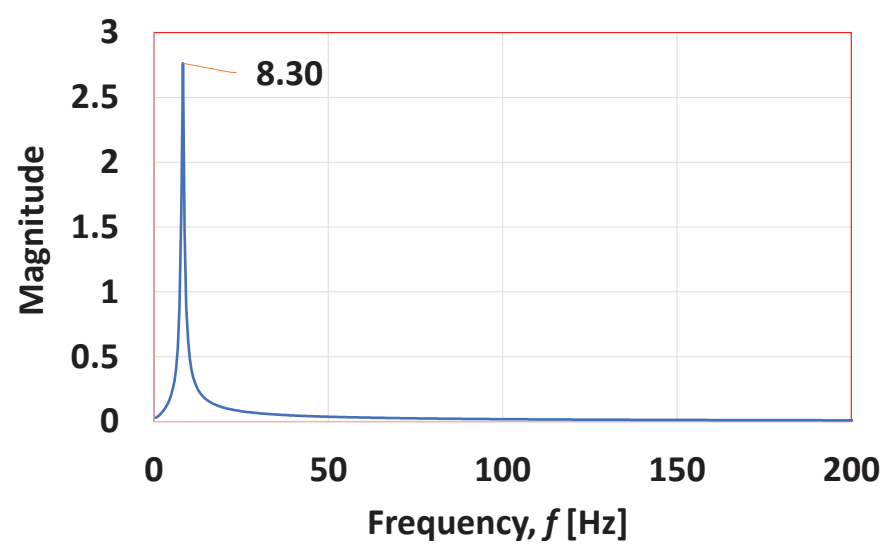

Fig. 7: The natural frequency of the SLFM.

\subsection{Time History Response with Excitation Force on Translational Motion}

Figure 8 shows the THR of lateral deformation with the excitation force of the SLFM system on the translational motion. Computational codes on THR of lateral deformation were developed based on the formulation explained in the previous section. In the calculation, the motor rotates the shaft within 2.5 seconds. This simulation calculates at a nodal point six of the link using the excitation force. The DC motor was operated within 2.5 seconds. It can be seen that the lateral deformation gets the minimum deviation at the value $-0.0035[\mathrm{~m}]$, and the maximum difference is $0.0032[\mathrm{~m}]$ at $\mathrm{t}=0[\mathrm{~s}]$ and $\mathrm{t}=0.5[\mathrm{~s}]$ due to the existence of the excitation force at the time, the minimum deviation at the value $-0.0037[\mathrm{~m}]$. The maximum deviation is $0.0034[\mathrm{~m}]$.

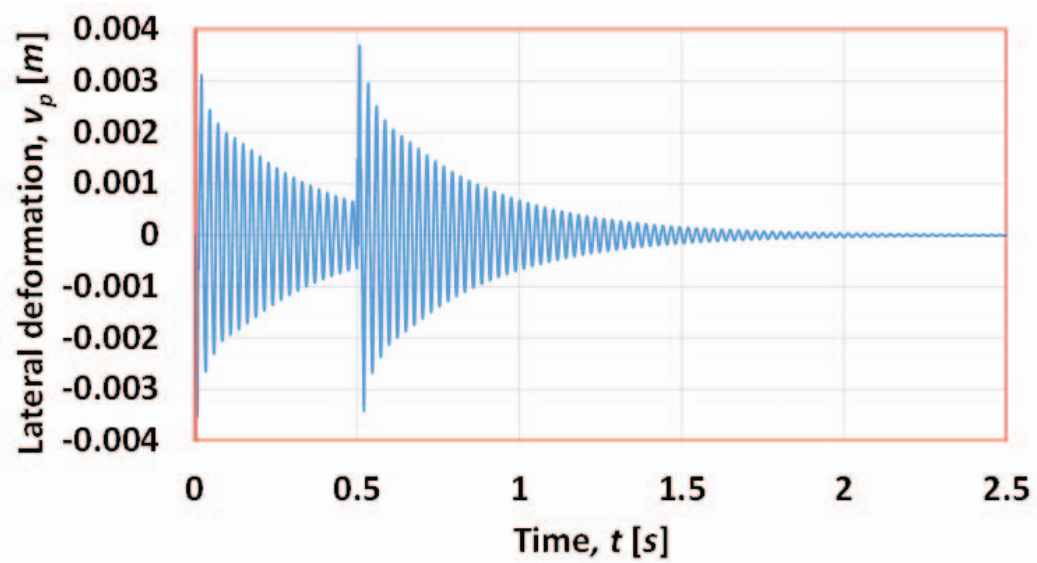

Fig. 8: THR on the system with excitation force experienced translational motion.

\subsection{Time History Response with Excitation Force on Translational and Rotational Motions}

The simulation results of translational and rotational motions obtain THR of lateral deformation using excitation forces on the system, as shown in Fig. 9. In this simulation, the DC motor for translational motion and servo motor rotates the link by the angle of $\pi / 2$ radians (90 degrees) within 2.5 seconds. It can be seen that the lateral deformation gets the maximum deviation is at the value 0.0077 [m], and the minimum difference is 0.0085 [m] at $\mathrm{t}=0[\mathrm{~s}]$. While, at time $\mathrm{t}=0.5[\mathrm{~s}]$ due to the existence of the excitation force at the time, the maximum deviation at the value 0.009 [m], and the minimum difference is $-0.0085[\mathrm{~m}]$. 


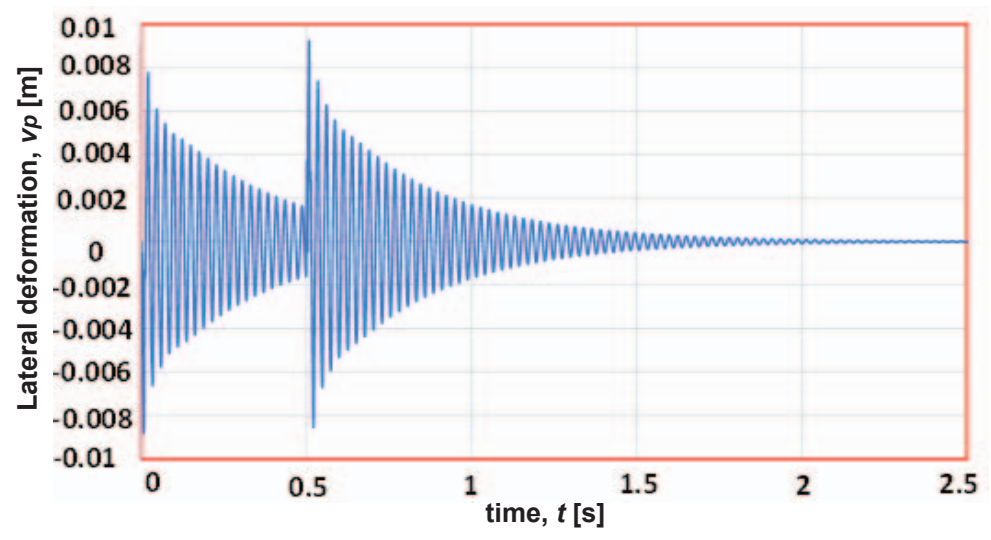

Fig. 9: THR on the SLFM with excitation force experienced translational and rotational motions.

\section{DISCUSSION}

This study focuses on the discretization of equations of motion in SLFM systems using FEM. When compared with research that has been done by Muhammad et al. [17], the results of simulations and experiments of rotational motion have the same tendency as shown on the THR graph. The damping factor and physical parameters determine vibration characteristics. The difference is that this study has installed vibration control in the system so that it produces smaller vibrations and voltages. Therefore, for further research, validation of the simulation results with the experimental method, and appropriate vibration control is needed to obtain high position accuracy.

\section{CONCLUSION}

This study has presented the dynamic modelling of the single-link flexible manipulator robot. The equation of motion for the single-link flexible manipulator that includes translational and rotational motion has been formulated using the finite-element method and the Lagrange equation. The computational code has been successfully developed and used in system dynamics simulations. The results are presented in the order of time history response and natural frequency with the FFT processing. For the translational and rotational motions, the lateral deformation is higher when compared to translational motion, and this is due to the presence of two kinetic energies that occur in the system, namely translational kinetic energy and rotational kinetic energy. This research indicates that vibrations that arise in SLFM that move translationally and rotationally are more significant when compared to the individual translational motion or rotational motion, due to the influence of the simultaneous movements that occur in the system. The presented dynamic model ignores the coupling effect and the action of the motor, therefore, this system requires experiment validation and vibration control for industrial applications and robotics.

\section{REFERENCES}

[1] Sabatini M, Gasbarri P, Monti R, Palmerini GB (2012). Vibration control of a flexible space manipulator during on orbit operations. Acta Astronaut. 73: 109-121. https://doi.org/10.1016/j.actaastro.2011.11.012.

[2] Nanos K, Papadopoulos EG (2015). On the dynamics and control of flexible joint space manipulators. Control Engineering
https://doi.org/10.1016/j.conengprac.2015.06.009.

Practice.

45:

230-243. . 
[3] Meng D, Wang X, Xu W, Liang B (2017). Space robots with flexible appendages: Dynamic modeling, coupling measurement, and vibration suppression. Journal of Sound and Vibration. 396: 30-50. https://doi.org/10.1016/j.jsv.2017.02.039.

[4] Gasbarri P, Pisculli A (2015). Dynamic/control interactions between flexible orbiting spacerobot during grasping, docking and post-docking manoeuvres. Acta Astronaut. 110: 225-238. https://doi.org/10.1016/j.actaastro.2015.01.024.

[5] Borovin GK, Lapshin V (2018). Motion planning of a space robot. in IOP Conference Series: Materials Science and Engineering PAPER. doi:10.1088/1757-899X/468/1/012020.

[6] Xu W, Meng D, Chen Y, Qian H, Xu Y (2014). Dynamics modeling and analysis of a flexiblebase space robot for capturing large flexible spacecraft. Multibody System Dynamics. 32: 357-401. doi:10.1007/s11044-013-9389-0.

[7] Qiu ZC (2012). Adaptive nonlinear vibration control of a Cartesian flexible manipulator driven by a ballscrew mechanism. Mechanical Systems and Signal Processing. 30: 248-266. http://dx.doi.org/10.1016/j.ymssp.2012.01.002.

[8] Shin H, Rhim S (2015). Modeling and control of lateral vibration of an axially translating flexible link. Journal of Mechanical Science and Technology. 29: 191-198. http://dx.doi.org/10.1007/s12206-014-1226-8.

[9] Yang H, Liu J, Lan X (2015). Observer design for a flexible-link manipulator with PDE model. Journal of Sound and Vibration. 341: 237-45. https://doi.org/10.1016/j.jsv.2014.12.033.

[10] Ata AA, Fares WF, Sa'adeh MY (2012). Dynamic Analysis of a Two-link Flexible Manipulator Subject to Different Sets of Conditions. Procedia Engineering. 41: 1253-1260. https://doi.org/10.1016/j.proeng.2012.07.308.

[11] Muhammad AK, Okamoto S, Lee JH (2014). Computer simulations on vibration control of a flexible single-link manipulator using finite-element method. in The Nineteenth International Symposium on Artificial Life and Robotics 22-24 January 2014; Beppu, Japan. pp. 381-386.

[12] Muhammad AK, Okamoto S, Lee JH (2015). Finite Element Analysis for Active-force Control on Vibration of a Flexible Single-link Manipulator. International Journal on Smart Material and Mechatronics (IJSMM). 2(2):106-109.

[13] Muhammad AK, Okamoto S, Lee JH (2014). Comparison of proportional-derivative and active-force controls on vibration of a flexible single-link manipulator using finite-element method. Artif Life Robotics. 19: 375-381. https://doi.org/10.1007/s10015-014-0186-5.

[14] Muhammad AK, Okamoto S, Lee JH (2015) Active-Force Control on Vibration of a Flexible Single-Link Manipulator Using a Piezoelectric Actuator. In: Transactions on Engineering Technologies. Edited by Yang GC, Ao SI, Huang X, Castillo O. Springer, Dordrecht; pp 115. doi:https://doi.org/10.1007/978-94-017-9588-3_1.

[15] Muhammad AK, Okamoto S, Lee JH (2014). Comparisons of proportional and active-force controls on vibration of a flexible link manipulator using a piezoelectric actuator through calculations and experiments. Engineering Letters. 22(3): 8.

[16] Muhammad AK, Okamoto S, Lee JH (2016). Comparison Between the One Piezoelectric Actuator and the Two Ones on Vibration Control of a Flexible Two-Link Manipulator Using Finite Element Method. International Journal of Mechanical Engineering 5(1): 27-44. 
http://www.iaset.us/view_archives.php?year=2016\&jtype=2\&id=67\&details=archives.

[17] Muhammad AK, Okamoto S, Lee JH (2014). Computational Simulations and Experiments on Vibration Control of a Flexible Link Manipulator Using a Piezoelectric Actuator. In proceedings of the International MultiConference of Engineers and Computer Scientists IMECS 2014. 1: 12-14 March 2014; Hong Kong.

[18] Mahto S (2014). Shape optimization of revolute-jointed single link flexible manipulator for vibration suppression. Mechanism and Machine Theory. 75: 150-160. https://doi.org/10.1016/j.mechmachtheory.2013.12.005.

[19] Dubay R, Hassan M, Li C, Charest M (2014). Finite element based model predictive control for active vibration suppression of a one-link flexible manipulator. ISA Transactions. 53(5): 1609-19. https://doi.org/10.1016/j.isatra.2014.05.023.

[20] Halim D, Luo X, Trivailo PM (2014). Decentralized vibration control of a multi-link flexible robotic manipulator using smart piezoelectric transducers. Acta Astronautica. 104(1): 186196. https://doi.org/10.1016/j.actaastro.2014.07.016.

[21] Yavuz Ş, Malgaca L. Karagülle H (2016). Vibration control of a single-link flexible composite manipulator. $\quad$ Composit $\quad$ Structur. https://doi.org/10.1016/j.compstruct.2016.01.037.

[22] Parashar SK, von Wagner U, Hagedorn P (2013). Finite element modeling of nonlinear vibration behavior of piezo-integrated structures. Computers \& Structures. 119: 37-47. https://doi.org/10.1016/j.compstruc.2012.12.026.

[23] Kadığlu F, Tekin G (2018). Mixed Finite Element Formulation for the Free Vibration Analysis of Viscoelastic Plates with Uniformly Varying Cross-Section. International Journal of Mechanical Engineering and Robotics Research 7(2): 235-239. https://doi.org/10.18178/ijmerr.7.3.235-239.

[24] Bien DX, My CA, Khoi PB (2018). Dynamic Modeling and Control of a Flexible Link Manipulators with Translational and Rotational Joints. VNU Journal of Science: Mathematics - Physics. 34(1): 52-66. https://doi.org/10.25073/2588-1124/vnumap.4240.

[25] Dermawan D, Abbas H, Syam R, Djafar Z, Muhammad AK (2019). Finite element analysis on vibration of a flexible single-link manipulator moved translationally. IOP Conference Series: Materials Science and Engineering. 619(1): 012050. https://doi.org/10.1088/1757899X/619/1/012050. 